\title{
Physiological and morphological responses of dormant and growing Norway spruce container seedlings to drought after planting
}

\author{
Pekka HELENIUS*, Jaana LUORANEN, Risto RIKALA \\ Finnish Forest Research Institute, Suonenjoki Research Station, Juntintie 154, 77600 Suonenjoki, Finland
}

(Received 17 March 2004; accepted 30 September 2004)

\begin{abstract}
Survival, root egress, height growth, xylem water potential, and chlorophyll fluorescence of dormant and growing Norway spruce (Picea abies (L.) Karst.) container seedlings exposed to postplanting drought periods (1, 2, 3 and 4 weeks) in the field were studied. Growth stages were created by terminating overwinter frozen storage 5 weeks (growing) or 5 days (dormant) before planting. Without postplanting drought, root egress of growing seedlings during the 6-week study period was twice that of dormant seedlings. When exposed to postplanting drought, growing seedlings showed a greater decline in root egress and xylem water potential than dormant seedlings. Postplanting drought had no effect on chlorophyll fluorescence in dormant seedlings, whereas in growing seedlings chlorophyll fluorescence decreased after the 3-week drought period. The results indicate that planting seedlings kept dormant by prolonged frozen storage in summer is beneficial only if very long dry periods occur after planting.
\end{abstract}

chlorophyll fluorescence / drought / growth stage / Picea abies / root egress

Résumé - Réaction physiologique et morphologique à la sécheresse après plantation de semis dormants ou en croissance de Picea abies cultivés en conteneurs. La survie, la production de nouvelles racines, la croissance de la pousse, le potentiel hydrique du xylème et la fluorescence de la chlorophylle ont été étudiés sur des semis de Picea abies (L.) Karst, dormants ou en croissance, cultivés en conteneurs et exposés à des périodes $(1,2,3$ et 4 semaines) de sécheresse après plantation au champ. Pour préparer les divers stades de croissance, le stockage hivernal des semis au froid a cessé 5 semaines (en croissance) ou 5 jours (dormants) avant la plantation. Quand les semis n'ont pas été exposés à la sécheresse après plantation, la production de nouvelles racines des semis en croissance a doublé comparativement aux semis dormants pendant les 6 semaines d'étude. Pour les semis exposés à la sécheresse après plantation, la production de nouvelles racines et le potentiel hydrique ont davantage baissé pour les semis en croissance que pour les semis dormants. La sécheresse après plantation n'a pas affecté la fluorescence de la chlorophylle des semis dormants, mais après une sécheresse de 3 semaines la fluorescence de la chlorophylle des semis en croissance a baissé. Les résultats montrent que la plantation des semis qui ont été conservés dormants par un stockage au froid plus long en été est bénéfique dans le cas où la sécheresse continue très longtemps après plantation.

fluorescence de la chlorophylle / sécheresse / stade de croissance / Piceas abies / production de nouvelles racines

\section{INTRODUCTION}

Nearly 150 million container-grown conifer seedlings, mostly Norway spruce (Picea abies (L.) Karst.), are annually delivered for planting in Finland (Finnish Ministry of Agriculture and Forestry, 2003). At present more than $30 \%$ of the seedlings are frozen stored. Seedlings are usually planted in three or four weeks in May before shoots start to elongate and soil is considered too dry for survival and growth. However, during the last 20 years the number of workers employed in silvicultural work, e.g. in planting, has decreased almost 50\% [7], and it is predicted that the decrease will continue in the near future.
Hence, planting all the seedlings with a decreasing number of workers necessitates an extended planting period. Moreover, extended planting period would ease spring workloads in nurseries and enable profitable mechanized planting. Therefore, producing planting material for an extended planting period requires rescheduling of the plant production chain to be able to grow morphologically and physiologically target seedlings for each time and site.

A major impediment to the extension of the spring planting period is the risk of drought. If the summer is warm, and if the precipitation and capillary rise of water from deeper soil layers are insufficient to compensate for transpiration, newly planted

\footnotetext{
* Corresponding author: pekka.helenius@metla.fi
} 
seedlings with restricted root systems are susceptible to water stress. In addition, seedlings that have been stored traditionally outdoors under snow cover, which usually persists until the end of April in central Finland, are already actively growing in June. Although they have high ability to root egress, their resistance against a number of stresses (e.g. drought, frost, mechanical stress, etc.) is low $[4,5,26]$. For example, the field performance of growing Norway spruce container seedlings has been shown to be reduced after a 2 -week drought period in warm weather [14]. Because drought periods lasting longer than two weeks occur in summer in Finland (based on the meteorological database at the Suonenjoki Research Station of Finnish Forest Research Institute), planting growing seedlings in summer may result in plantation failure especially if soil is dry at the time of planting.

Since the stress resistance is closely related to the phenological stage of seedlings [3, 8], it should be possible to decrease the risk of plantation failure due to drought in early summer by planting dormant or short-day treated seedlings instead of growing ones. However, due to the late start of the growing season at northern latitudes, short-day treatment cannot be applied economically to produce hardened seedlings yet for June planting. Dormancy, instead, can be maintained until the time of the planting by prolonged overwinter frozen storage. Provided that seedlings coming-out-of-dormancy perform better under drought than growing seedlings, successful extension of the planting period would only be a matter of scheduling the delivery of frozen-stored seedlings later than that of outdoor-stored seedlings.

In central Finland frozen storage can be prolonged at most until mid-June without the risk of frost damage to seedlings in autumn [10, 22]. Since the frozen storage of spring planted seedlings is usually initiated in October, prolongation would account for a storage period of over 30 weeks. Long storage periods may, however, affect the postplanting performance, especially if seedlings are exposed to water stress after planting $[12,16,17]$. In addition, dormant seedlings initiating new growth after planting allocate preferentially more photosynthates to shoot growth compared to root growth [8], which may reduce the ability to maintain balanced seedling water relations when exposed to drought. Besides the obvious effect on seedling water relations (whether seedlings are dormant or growing), drought may also affect needle chlorophyll fluorescence [1], and when severe and long-lasting, also growth and survival.

The aim of this study was to determine if the risk of plantation failure due to drought in early summer could be decreased by planting dormant seedlings after prolonged frozen storage instead of growing seedlings from the same seedling stock. To achieve this aim, we compared physiological and morphological responses of dormant and growing seedlings to postplanting drought under experimental field conditions.

\section{MATERIALS AND METHODS}

\subsection{Seedling material}

Norway spruce seeds obtained from a registered seed orchard (No. 113, Kangasniemi 61 ${ }^{\circ} 54^{\prime} \mathrm{N}, 26^{\circ} 40^{\prime}$ E, $100 \mathrm{~m}$ a.s.1.) were sown on hard plastic containers (Plantek 81F, Lannen, Co., Finland; cell volume $85 \mathrm{~cm}^{3}$ ) filled with base-fertilized sphagnum peat (Kekkila
Table I. Morphological attributes (mean \pm SD) of subsamples $(n=$ 40 ) of dormant and growing seedlings at the beginning of the experiment (24 June).

\begin{tabular}{lcc}
\hline Attribute & $\begin{array}{c}\text { Dormant } \\
\text { seedlings }\end{array}$ & $\begin{array}{c}\text { Growing } \\
\text { seedlings }\end{array}$ \\
\hline Height $(\mathrm{cm})$ & $19.1 \pm 2.1$ & $28.3 \pm 2.6$ \\
Stem diameter $(\mathrm{mm})$ & $2.6 \pm 0.3$ & $3.4 \pm 0.4$ \\
Shoot dry weight $(\mathrm{g})$ & $1.04 \pm 0.19$ & $1.94 \pm 0.43$ \\
Root dry weight $(\mathrm{g})$ & $0.43 \pm 0.10$ & $0.51 \pm 0.11$ \\
Root to shoot ratio & 0.41 & 0.26 \\
\hline
\end{tabular}

Co., Finland) on 20 April 2001. Seedlings were grown in a greenhouse at the Suonenjoki Research Nursery (62 $39^{\prime}$ N, $27^{\circ} 03^{\prime}$ E, $142 \mathrm{~m}$ a.s.1.) until 16 July, when they were transferred to an outdoor growing area. During the first growing season, seedlings were irrigated regularly to keep the water content of peat at $40-50 \%\left(\mathrm{v} \mathrm{v}^{-1}\right.$; by volume), and they were fertilized altogether 18 times between 14 June and 12 September with liquid Taimi-superX fertilizer (Kekkila Co., Finland) (a total of $54 \mathrm{mg} \mathrm{N}, 14 \mathrm{mg} \mathrm{P}$ and $57 \mathrm{mg} \mathrm{K}$ per seedling plus micronutrients). On 23 October 2001, seedlings were extracted from the containers and placed upright in plastic trays $(490 \mathrm{~mm} \times 290 \mathrm{~mm} \times 70 \mathrm{~mm}, 63$ seedlings per tray) that were inserted into cardboard boxes ( 2 trays per box). Two dataloggers (HOBO, Pro Series, USA) were inserted in randomly selected boxes to record temperature and relative humidity during storage. Boxes were then transferred to frozen storage $\left(-3.5^{\circ} \mathrm{C}\right)$. The temperature inside the boxes decreased from $7{ }^{\circ} \mathrm{C}$ (outdoor temperature) to $-3.4{ }^{\circ} \mathrm{C}$ in 23 days. Thereafter, the temperature varied between -2.4 and $-5.3{ }^{\circ} \mathrm{C}$ (mean $-3.5^{\circ} \mathrm{C}$ ) and relative humidity between 96.7 and $99.9 \%$ (mean $98.3 \%$ ) during the rest of the storage period.

On 20-24 May 2002, after 30 weeks, half of the seedling stock (five boxes) were removed from the frozen storage (one box per day) and thawed at $+12{ }^{\circ} \mathrm{C}$ in the dark for 3 days. After thawing, seedlings were taken out of the boxes and acclimated to light in an outdoor shelter for 2 days (the shelter shaded $89 \%$ of the photosynthetically active radiation, PAR). Seedlings were returned to the containers and transferred to the outdoor growing area, where they were grown under normal nursery culture regime until the beginning of the experiment. Seedlings were irrigated regularly and fertilized three times with liquid Taimi-superX fertilizer (a total of $12 \mathrm{mg} \mathrm{N}, 2.5 \mathrm{mg} \mathrm{P}$ and $13 \mathrm{mg} \mathrm{K}$ per seedling plus micronutrients) in order to avoid any decrease in seedling nutrient concentration before the experiment. These seedlings are referred to below as growing seedlings. The rest of the seedlings (five boxes) were kept in the frozen storage until 19-23 June 2002 (frozen storage duration 34 weeks), when they were likewise removed from storage, thawed, acclimated to light and returned to the containers as described above. These seedlings are referred to below as dormant seedlings. Seedling morphology at the beginning of the experiment (24 June) is given in Table I.

To measure possible carbohydrate depletion during the 4-week prolongation of the frozen storage, needle samples were collected on three occasions: (I) 23 October 2001, before the seedlings were placed into frozen storage, (II) 20-22 May 2002, after the 30-week storage (growing seedlings) and (III) 19-21 June 2002, after the 34-week storage (dormant seedlings). On each occasion, 15 seedlings were randomly selected and divided into three groups (subsamples). From each seedling, 15 needles were collected from the middle section of the shoot, dried at $60^{\circ} \mathrm{C}$ for $72 \mathrm{~h}$ and powdered. The samples were extracted and soluble sugars and starch were analyzed as described by Hansen and Møller [11] and Iivonen et al. [15]. The concentration of 
soluble sugars in needles were $146.0 \pm 3.4,110.4 \pm 2.4$ and $115.0 \pm$ $4.0 \mathrm{mg} \mathrm{g}^{-1}$ dry weight (mean \pm SD) and the concentration of starch were $33.0 \pm 1.0,33.7 \pm 1.0$ and $30.7 \pm 1.7 \mathrm{mg} \mathrm{g}^{-1}$ dry weight (mean \pm $\mathrm{SD}$ ) on the first, second and third sampling date, respectively.

\subsection{Experimental design}

Root egress and height growth were studied by exposing dormant and growing seedlings to different postplanting drought periods $(0,1$, 2,3 and 4 weeks) on a sandy experimental field site. To homogenize soil conditions, vegetation cover and organic layer were removed from the field site. The percentages of the dominant particle size $(0.2-$ $0.6 \mathrm{~mm}$ ) in the site varied between 65 and 72 . The soil was free from clay material, and the content of organic matter was low (loss of ignition at $550{ }^{\circ} \mathrm{C}$ for $3 \mathrm{~h}$ ranged from 0.8 to $1.8 \%$ ). Water-retention characteristics of the soil in the field site are presented in Heiskanen and Rikala [13]. The site $(10 \times 30 \mathrm{~m})$ was covered with a plastic rain shelter placed at a height of about $2 \mathrm{~m}$. The shelter shaded $\sim 35 \%$ of PAR measured at ground level (LI-COR LI-185B quantum sensor). Randomly selected seedlings were well-watered and new roots grown out from the root plug were cut. Then the seedlings were planted under the rain shelter in a split-plot design consisting of five blocks divided into five plots (one plot for each postplanting drought period). In each plot there were subplots of 15 dormant and 15 growing seedlings in a grid measuring $25 \times 25 \mathrm{~cm}$ (a total of 750 seedlings: 5 blocks $\times$ 5 drought periods $\times 2$ subplots $\times 15$ seedlings). As seedlings were removed from the frozen storage and thawed on 5 consecutive days, the blocks (No. 1-5) were likewise planted in numerical order on 5 consecutive days (24, 25, 26, 27 and 28 June). Postplanting drought periods were created in plots by withholding irrigation for either 0,1 , 2, 3 or 4 weeks. After drought periods, plots were irrigated manually with $15 \mathrm{~mm}$ tapwater twice a week so that the drought period plus irrigation lasted 6 weeks (i.e. 1 -week drought period +5 weeks irrigation, etc.). The combination of drought period and irrigation is referred to below as the study period. Control plots ( 0 -week drought period) were irrigated from the beginning of the experiment. To ascertain the availability of water to seedlings after drought periods, the amount of irrigation given (15 mm twice a week) was somewhat higher than the mean weekly precipitation in July in central Finland.

Shoot xylem water potential ( $\left.\Psi_{\text {shoot }}\right)$ and needle chlorophyll fluorescence of dormant and growing seedlings were studied before planting and after four postplanting drought periods (1, 2, 3 and 4 weeks) on the same experimental field site as root egress and height growth. On 25 June, additional 100 dormant and growing seedlings were randomly selected from the seedling stock. Of these, 80 well-watered seedlings from both groups were planted in a separate block (No. 6) on 26 June. The block consisted of four plots, each having 20 dormant and 20 growing seedlings receiving no irrigation. The remaining 20 seedlings in both groups were reserved for measurement of preplanting $\Psi_{\text {shoot }}$ and chlorophyll fluorescence.

\subsection{Measurements}

\subsubsection{Survival, root egress and height growth}

After the 6-week study period, seedlings in blocks 1-5 were lifted and visually rated as dead or alive by the presence or absence of turgid green needles. Extensive root damage caused by summer chefer larvae (Amphimallon solstitiale L.) was observed in 9 dormant and 5 growing seedlings, most of them in block 4 . These seedlings were excluded from further measurements and analysis. Height growth of surviving seedlings was determined $( \pm 1 \mathrm{~mm})$ on the basis of the difference between initial height and final height (both measured from the surface
Table II. Mean weekly temperature $\left({ }^{\circ} \mathrm{C}\right)$ and relative humidity $(\%)$ at the soil surface level during the study period.

\begin{tabular}{lcc}
\hline Week & Temp. $\left({ }^{\circ} \mathrm{C}\right)$ & RH $(\%)$ \\
\hline 24-30 June & 13.9 & 74.4 \\
01-07 July & 17.0 & 69.3 \\
08-14 July & 21.2 & 52.1 \\
15-21 July & 20.5 & 62.5 \\
22-28 July & 19.3 & 61.3 \\
29 July-04 August & 20.2 & 51.3 \\
05-11 August & 18.1 & 58.0 \\
\hline
\end{tabular}

of the root plug to the terminal bud or terminal meristem). Roots that had grown out from the root plug (root egress) of surviving seedlings were cut, washed and dried in an oven $\left(48 \mathrm{~h}\right.$ at $\left.105^{\circ} \mathrm{C}\right)$ and weighed $( \pm 1 \mathrm{mg})$.

\subsubsection{Shoot xylem water potential and needle chlorophyll fluorescence}

On 25 June, 20 dormant and 20 growing seedlings reserved for measurement of preplanting values of $\Psi_{\text {shoot }}$ and chlorophyll fluorescence were transferred in containers to the field site and placed on the ground next to block No. 6. At northern latitudes nights are short and light in July. To eliminate possible variation in $\Psi_{\text {shoot }}$ due to weather conditions (clear or cloudy sky) during the nights preceding the measurements, the containers were covered at $2200 \mathrm{~h}$ with a black cloth (LS-100) wrapped over a wooden frame $(130 \times 150 \times 44 \mathrm{~cm})$ to create an artificial night. Photon flux density of PAR under the frame was $0.25 \mu \mathrm{mol} \mathrm{m}-2 \mathrm{~s}^{-1}$ measured at $1000 \mu \mathrm{mol} \mathrm{m}{ }^{-2} \mathrm{~s}^{-1}$ (LI-COR LI-185B quantum sensor). The frame was removed at $0500 \mathrm{~h}$ the next morning and 10 seedlings from both groups (dormant + growing) were transferred to the laboratory in a cool bag. In the laboratory, the seedling shoots were excised $4-8 \mathrm{~cm}$ below the terminal bud scar and measured for simulated predawn xylem water potential ( $\left.\Psi_{\text {shoot pd }}\right)$ using a pressure chamber [27]. Another 10 seedlings from both groups were transferred to the laboratory at $1400 \mathrm{~h}$ and measured for daytime xylem water potential $\left(\Psi_{\text {shoot d }}\right)$. After daytime measurement, previous year needle chlorophyll fluorescence of the same seedlings from both groups was measured with a MINI-PAM fluorometer (Heinz Walz $\mathrm{GmbH}$, Effeltrich, Germany). From each seedling, 15 needles were collected below the excision point and dark adapted at room temperature for $35 \mathrm{~min}$ before fluorescence was measured using a 1-s saturating pulse of $9000 \mu \mathrm{mol} \mathrm{m}-2 \mathrm{~s}^{-1}$. The ratio of variable $\left(\mathrm{F}_{\mathrm{v}}\right)$ to maximal $\left(\mathrm{F}_{\mathrm{m}}\right)$ chlorophyll fluorescence was used as a quantitative measure of the photochemical efficiency of the photosystem II (PS II). Xylem water potential ( $\Psi_{\text {shoot pd }}$ and $\left.\Psi_{\text {shoot d }}\right)$ and chlorophyll fluorescence measurements were repeated, as described above, after 1-, 2-, 3- and 4-week drought periods using the seedlings planted in block No. 6. Blackout (artificial night) was used only during the nights preceding the measurements.

\subsection{Weather and edaphic conditions}

Air temperature and relative humidity at the field site were monitored during the study period using a thermohygrograph (Lambrecht, West Germany) placed in a weather cabin at the soil surface level (Tab. II). Midsummer 2002 was slightly warmer than the 30-yr average (1972-2001) at the Suonenjoki Research Station. The mean temperature during the study period ( 24 June-9 August) was $0.6^{\circ} \mathrm{C}$ above 
Table III. Analysis of variance for the effects of drought periods (D), stage of seedling at planting (S) and block (B) on root egress during the 6-week study period $(n=730)$. MS $=$ mean squares, $\mathrm{Df}=$ degrees of freedom, $F=F$-test, $p=$ level of significance.

\begin{tabular}{lcccc}
\hline Source & Df & MS & $F$ & $p$ \\
\hline Drought (D) & 4 & 23970.1 & 33.5 & $<0.001$ \\
Block (B) & 4 & 1211.9 & 1.6 & 0.2 \\
Whole-plot error & 16 & 713.9 & & \\
Stage (S) & 1 & 13122.0 & 21.8 & $<0.001$ \\
D $\times$ S & 4 & 21361.5 & 35.5 & $<0.001$ \\
Sub-plot error & 20 & 600.2 & & \\
\hline
\end{tabular}

the long-term average. Soil water content was measured with portable time domain reflectometry (TDR; Trime-FM, Imko Micromodultechnik, Germany) twice a week from plots exposed to 0- and 4-week drought periods ( 5 measurements per plot) in all blocks. At the beginning of the study period the soil water content was $4.5-5 \%\left(\mathrm{v} \mathrm{v}^{-1}\right.$; by volume) and it decreased to $2.6-3 \%$, during the 4 -week drought period. Corresponding matric potentials, based on earlier study in the same field [13], were approximately -0.07 and $<-0.1 \mathrm{MPa}$, respectively. Irrigation $(15 \mathrm{~mm})$ after the 4 -week drought increased the soil water content to $9.5-10.5 \%$ (matric potential approx. $-0.01 \mathrm{MPa}$ ) measured $24 \mathrm{~h}$ after irrigation. In plots that were irrigated from the beginning of the study period ( 0 -week drought period) the soil water content was $9-10.7 \%$ (measured $24 \mathrm{~h}$ after irrigation).

\subsection{Statistical analysis}

Root egress, height growth and xylem water potential data were subjected to an analysis of variance (ANOVA). Differences in xylem water potential values between dormant and growing seedlings were analyzed with paired t-test after each drought period. Because it was not possible to transform distributions to normal and to homogenize the variances, differences in chlorophyll fluorescence between dormant and growing seedlings after each drought period and differences between drought periods were analyzed with Mann-Whitney U-test [29]. Dead seedlings and seedlings whose roots were damaged by summer chefer larvae were excluded from all analyses. Data were analysed using SPSS 11.0 for Windows (SPSS Inc.).

\section{RESULTS}

Mortality was low (on average $<1 \%$ ) during the study period. Only two dormant seedlings, one each in the 2- and 3week drought periods, and four growing seedlings, all of them in 4-week drought period died. Consequently, no clear effect of either growth stage of seedlings at planting or postplanting drought on mortality could be found.

Both growth stage of seedlings at planting (dormant/growing) and drought period had a significant effect on root egress (Tab. III). Root egress for seedlings that were growing at planting was twice that for dormant seedlings during the study period under regular irrigation (0-week drought period). However, root egress in growing seedlings declined in 2-week, and especially in 3- and 4-week drought exposure (Fig. 1a). There was a significant interaction between the growth stage of the seed-
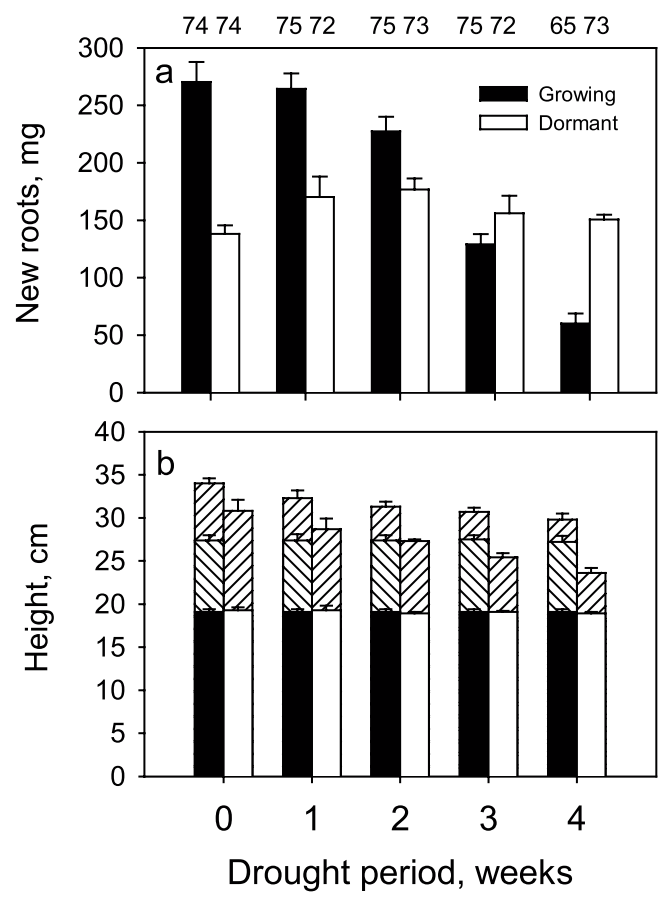

$$
\begin{aligned}
& \text { Height growth after planting } \\
& \text { Height growth before planting } \\
& \text { Growing } \\
& \text { Dormant }
\end{aligned}
$$

Figure 1. (a) Mean dry mass (mg) of new roots grown out from the root plug (root egress), and (b) initial heights, height growth of growing seedlings before planting and height growth of dormant and growing seedlings, when exposed to different postplanting drought periods $(0,1,2,3$ and 4 weeks $)$. After the drought periods seedlings were irrigated twice a week so that drought period plus irrigation lasted 6 weeks (i.e. 1-week drought period +5 weeks irrigation, etc.). Vertical bars indicate the standard error of the mean. The number of observations in each treatment is marked above every column (dead seedlings and seedlings damaged by summer chefer larvae excluded).

lings and drought on root egress (Tab. III): root egress was consistently higher in growing seedlings than in dormant seedlings in the shortest drought periods $(0,1$ and 2 weeks). However, when exposed to 3- and 4-week drought periods, root egress was higher in dormant than in growing seedlings (Fig. 1a).

Due to the 4-week difference in frozen storage duration, dormant seedlings were approximately $9 \mathrm{~cm}$ shorter than growing seedlings at the time of planting (Tab. I and Fig. 1b). Height growth decreased almost linearly as the drought period lengthened both in dormant and growing seedlings $(p<0.001)$ (Fig. 1b). Although there was a weak significant interaction ( $p=0.043$ ) between the growth stage of the seedlings at planting and drought on height growth, height growth was in general $50 \%$ lower in growing seedlings than in dormant seedlings during the study period excluding the 0 -week drought period (Fig. 1b).

Initially, $\Psi_{\text {shoot pd }}$ and $\Psi_{\text {shoot d }}$ values were lower in dormant seedlings than in growing seedlings $(p<0.001)$. In dormant seedlings, $\Psi_{\text {shoot pd }}$ remained at rather constant levels during 1-, 2- and 3-week drought periods, whereas in growing seedlings, 

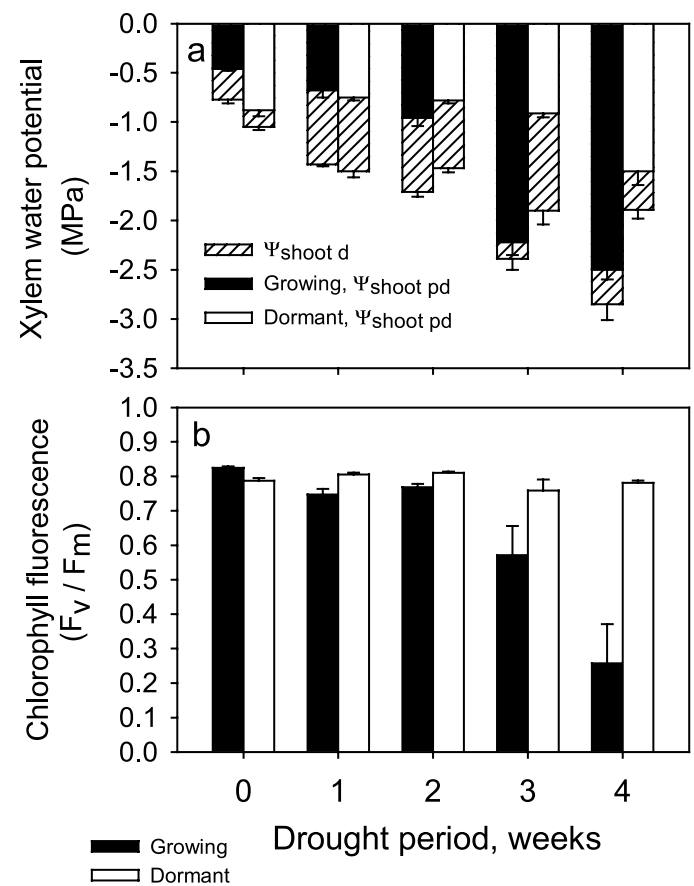

Figure 2. (a) Predawn and daytime shoot xylem water potentials ( $\Psi_{\text {shoot pd }}$ and $\Psi_{\text {shoot d }}$ ), and (b) chlorophyll fluorescence $\left(\mathrm{F}_{\mathrm{v}} / \mathrm{F}_{\mathrm{m}}\right)$ of the previous year needles in dormant and growing seedlings before planting (0) and after 1-, 2-, 3- and 4-week postplanting drought periods. Vertical bars indicate the standard error of the mean. In $\Psi_{\text {shoot pd }}$ and $\Psi_{\text {shoot d }}$ measurements there were 10 observations in each treatment except in growing seedlings after 4-week drought, where 6 and 4 observations, respectively. In chlorophyll fluorescence measurements there were likewise 10 observations in each treatment except in growing seedlings after 4-week drought, where 5 observations.

$\Psi_{\text {shoot pd }}$ declined after the first and second, and especially after the third week of drought. (Fig. 2a). There was a significant interaction between the growth stage of seedlings and the drought period on $\Psi_{\text {shoot pd }}$ and $\Psi_{\text {shoot d }}(p<0.001)$, both being lower in growing seedlings than in dormant seedlings after the third and fourth week of drought.

Both growth stage of seedlings and drought period had significant effect on needle chlorophyll fluorescence $\left(\mathrm{F}_{\mathrm{v}} / \mathrm{F}_{\mathrm{m}}\right.$ ratio $)$ $(p<0.001) . \mathrm{F}_{\mathrm{V}} / \mathrm{F}_{\mathrm{m}}$ ratio of the needles of dormant seedlings seemed rather insensitive to drought and was, in general, higher than in growing seedlings in all drought periods except the shortest one (Fig. 2b). A clear decline in $F_{v} / F_{m}$ ratio was observed in growing seedlings exposed to 3- and 4-week drought periods. As in root egress and water potential values, a significant interaction was also observed between the growth stage of seedlings and the drought period on chlorophyll fluorescence values $(p<0.001)$.

\section{DISCUSSION}

Seedlings that were growing at planting showed considerably greater root egress during the study period than dormant seedlings when irrigated regularly or exposed to short drought periods (1-2 weeks). This can primarily be seen as a result of the different timing of shoot and root growth, and the importance of current photosynthate to new root growth [32]. After budbreak, provided that seedlings are not exposed to severe drought, the shoot is the primary sink of photosynthates which results in increases in shoot growth in preference to root growth [19]. Such a pattern was clearly seen in shoot and root growth of dormant seedlings under regular irrigation, indicating also that the normal growth rhythm was unaffected during the relatively long (34 weeks) frozen storage. In growing seedlings, however, allocation of photosynthates to roots probably increased during the study period. For example, Kaakinen et al. [18] found a considerable increase in root biomass simultaneously with ceasing stem elongation after mid-July in 1-yr-old Norway spruce seedlings that had initiated stem elongation in early June. In addition, growing seedlings initially had more unsuberized root biomass than dormant seedlings, which may have contributed to the greater water uptake and further, also greater root egress. The difference in root egress between dormant and growing seedlings under regular irrigation might also be related to the difference in frozen storage duration, as was shown by Ritchie [25] in Douglas-fir seedlings. However, the 4-week prolongation of frozen storage did not affect either soluble sugar or starch content in needles.

When seedlings were exposed to drought after planting, root egress of growing seedlings showed a considerable decline. On the other hand, root egress in dormant seedlings was rather insensitive to drought, and was in fact slightly increased by a short (1-2 weeks) exposure to drought (Fig. 1a). It is possible that a short period of low soil water content stimulates root egress of newly planted seedlings, at least as long as severe water deficit is avoided. Correspondingly, constant high soil water availability near the root plug may reduce the need for rapid root egress [8]. In growing seedlings, the decline in root egress almost paralleled the decline of $\Psi_{\text {shoot pd }}$. The most rapid decline in root egress was observed after the 3-week drought period, when the $\Psi_{\text {shoot pd }}$ was already $-2.2 \mathrm{MPa}$ (after blackout), and the difference between $\Psi_{\text {shoot pd }}$ and $\Psi_{\text {shoot d }}$ only $0.17 \mathrm{MPa}$. This observation shows that the growing seedlings failed to rehydrate during the night and suffered from severe water deficit. Since the $\Psi_{\text {shoot }}$ measurements were taken after the artificial night, $\Psi_{\text {shoot pd }}$ was probably even more negative in seedlings that were growing without blackout. It seems likely that after the 3-week drought photosynthesis was nearly zero in growing seedlings since a compensation point in net photosynthesis between -2.0 and $-3.0 \mathrm{MPa}(\Psi)$ has been reported for many spruce species [2, 9, 24, 28]. At the same time, dormant seedlings were still capable of restoring water balance during the night (Fig. 2a). Even though dormant seedlings also suffered from moderate water stress after the 4-week drought, no decrease in root egress was observed (Figs. 1a and 2a). However, height growth, i.e. increase in transpiring needle area, decreased, which is a typical drought-avoidance strategy $[20,21]$.

An obvious reason for the more rapid decline in $\Psi_{\text {shoot pd }}$ in growing seedlings compared to dormant seedlings is their larger needle area and probably complete dehardening at the time of the planting, which resulted in increases both in stomatal and especially cuticular transpiration. According to Tranquillini [31], complete cuticular development in spruce needles 
takes a minimum of 3 months after budburst. Due to the succulent state of new shoots and poorly developed cuticles of new needles, growing seedlings were not able to control the water loss to the same extent as the dormant seedlings. This, together with low root/shoot ratio overcame the positive effect of high root egression on their ability to exploit soil water and maintain seedling water balance.

Photochemical efficiency $\left(\mathrm{F}_{\mathrm{v}} / \mathrm{F}_{\mathrm{m}}\right)$ of the needles in dormant seedlings was still unaffected after the 4-week drought period at $\Psi_{\text {shoot pd }}$ value of $-1.5 \mathrm{MPa}$ (Figs. $2 \mathrm{a}$ and $2 \mathrm{~b}$ ). This is in agreement with the findings of Eastman and Camm [6] for interior spruce (Picea glauca (Moench) Voss $\times$ P. engelmannii Parry hybrid complex) seedlings. In growing seedlings $F_{v} / F_{m}$ ratio declined by $25 \%$ after the 3 -week drought period, while the $\Psi_{\text {shoot pd }}$ declined from $-0.96 \mathrm{MPa}$ to $-2.22 \mathrm{MPa}$, indicating probably down-regulation of primary photochemistry and the augmentation of photoprotective mechanisms to avoid overreduction and photoinhibitory damage [6]. A further decline in $\mathrm{F}_{\mathrm{v}} / \mathrm{F}_{\mathrm{m}}$ ratio after the 4-week drought period indicates that the photosynthetic apparatus of the growing seedlings was already damaged (Fig. 2b).

When the results of this study are examined, it should be taken into account that seedling performance under drought is dependent on the ambient weather conditions (i.e. air temperature and relative humidity) [33]. It is possible that the degree of water stress is more dependent on the weather conditions in growing seedlings due to their higher transpiring needle area than in dormant seedlings. For example, the rapid decline in xylem water potential and root egress over a 3 -week drought period in growing seedlings may be partly related to the rise of air temperature during the third week of the growing period (Tab. II). It is also possible that high root egression ability of growing seedlings has a more pronounced effect on the maintenance of seedling water balance if, contrary to the present study, soil water content is high at the beginning of the drought period. Finally, it must be remembered that the results from this study are not directly applicable to actual forest site, where newly planted seedlings have to compete with ground vegetation for water and nutrients [23, 30].

\section{CONCLUSIONS}

The results indicate that planting dormant Norway spruce container seedlings instead of growing ones from the same original seedling stock in early summer is beneficial only if very long dry period occur after planting. However, prolonged frozen storage (up to 34 weeks) in cardboard boxes at $-3.5^{\circ} \mathrm{C}$ is a useful method, with no major negative effect on seedling performance, to maintain dormancy until the time of the planting. Long term studies on performance of dormant and growing seedlings under drought on actual forest regeneration sites are needed before recommendations can be made.

Acknowledgements: This study was supported by a grant from the Metsämiesten Säätiö Foundation to Pekka Helenius. The authors would like to thank Ms. Ritva Pitkänen and Ms. Anna-Maija Väänänen for technical assistance and Dr. Henry Fullenwider and Ms. Hanna Ruhanen for assistance in copyediting.

\section{REFERENCES}

[1] Binder W.D., Fielder P., Mohammed G.H., L'Hirondelle S.J., Applications of chlorophyll fluorescence for stock quality assessment with different types of fluorometers, New For. 13 (1997) 63-89.

[2] Brix H., Effects of plant water stress on photosynthesis and survival of four conifers, Can. J. For. Res. 9 (1979) 160-165.

[3] Colombo S.J., Glerum C., Webb D.P., Daylength, temperature and fertilization effects on desiccation resistance, cold hardiness and root growth potential of Picea mariana seedlings, Ann. For. Sci. 60 (2003) 307-317.

[4] Coutts M.P., Effects of root or shoot exposure before planting on the water relations, growth, and survival of Sitka spruce, Can. J. For. Res. 11 (1981) 703-709.

[5] Deans J.D., Lundberg C., Tabbush P.M., Cannell M.G.R., Sheppard L.J., Murray M.B., The influence of desiccation, rough handling and cold storage on the quality and establishment of Sitka spruce planting stock, Forestry 63 (1990) 129-141.

[6] Eastman P.A.K., Camm E.L., Regulation of photosynthesis in interior spruce during water stress: changes in gas exchange and chlorophyll fluorescence, Tree Physiol. 15 (1995) 229-235.

[7] Elovirta P., Forest sector's labour force, in: Finnish Statistical Yearbook of Forestry, Finnish Forest Research Institute, SVT Agriculture, forestry and fishery, 2002, pp. 217-238.

[8] Grossnickle S.C., Ecophysiology of northern spruce species: the performance of planted seedlings, NRC, Research Press, Ottawa, Ontario, Canada, 2000.

[9] Grossnickle S.C., Fan S., Genetic variation in response to drought of interior spruce (Picea glauca (Moench) Voss $\times$ P. engelmannii Parry ex Engelm.), Scand. J. For. Res. 14 (1999) 251-261.

[10] Hänninen H., Luoranen J., Smolander H., Rikala R., Istutusajankohdan vaikutus pakkasvarastoitujen taimien hallavaurioriskiin syksyllä Keski-Suomessa, in: Poteri M. (Ed.), Taimitarhatutkimuksen vuosikirja 2002, Metsäntutkimuslaitoksen tiedonantoja 873, 2002, pp. 59-68 (in Finnish).

[11] Hansen J., Møller I., Percolation of starch and soluble carbohydrates from plant tissue for quantitative determination with anthrone, Anal. Biochem. 68 (1975) 87-94.

[12] Harper G.J., Camm E.L., Effects of frozen storage duration and soil temperature on the stomatal conductance and net photosynthesis of Picea glauca seedlings, Can. J. For. Res. 23 (1993) 2459-2466.

[13] Heiskanen J., Rikala R., Effect of peat-based container media on establishment of Scots pine, Norway spruce and silver birch seedlings after transplanting in contrasting water conditions, Scand. J. For. Res. 15 (2000) 49-57.

[14] Helenius P., Luoranen J., Rikala R., Leinonen K., Effect of drought on growth and mortality of Norway spruce container seedlings planted in summer, Scand. J. For. Res. 17 (2002) 218-224.

[15] Iivonen S., Rikala R., Vapaavuori E., Seasonal root growth of Scots pine seedlings in relation to shoot phenology, carbohydrate status, and nutrient supply, Can. J. For. Res. 31 (2001) 1569-1578.

[16] Jiang Y., Zwiazek J.J., MacDonald S.E., Effects of prolonged cold storage on carbohydrate and protein content and field performance of white spruce bareroot seedlings, Can. J. For. Res. 24 (1994) $1369-1375$.

[17] Jiang Y., MacDonald S.E., Zwiazek J.J., Effects of cold storage and water stress on water relations and gas exchange of white spruce (Picea glauca) seedlings, Tree Physiol. 15 (1995) 267-273.

[18] Kaakinen S., Jolkkonen A., Iivonen S., Vapaavuori E., Growth, allocation and tissue chemistry of Picea abies seedlings affected by nutrient supply during the second growing season, Tree Physiol. 24 (2004) 707-719. 
[19] Kramer P.J., Kozlowski T.T., Physiology of woody plants, Academic Press, New York, San Francisco, London, 1979.

[20] Larcher W., Physiological plant ecology, ecophysiology and stress physiology of functional groups, 3rd ed., Springer-Verlag, Berlin, Heidelberg, 1995.

[21] Levitt J., Responses of plants to environmental stresses, Vol. II, Water, salt, radiation and other stresses, Academic Press, New York, 1980

[22] Luoranen J., Konttinen K., Rikala R., Smolander H., Ennakkotuloksia kuusen paakkutaimien kesäistutuksesta, in: Poteri M. (Ed.), Taimitarhatutkimuksen vuosikirja 2001, Metsäntutkimuslaitoksen tiedonantoja 813, 2001, pp. 24-31 (in Finnish).

[23] Nilsson U., Örlander G., Response of newly planted Norway spruce seedlings to fertilization, irrigation and herbicide treatments, Ann. For. Sci. 60 (2004) 637-643.

[24] Patterson T.B., Guy R.D., Dang Q.L., Whole-plant nitrogen- and water relations traits, and their associated trade-offs, in adjacent muskeg and upland boreal spruce species, Oecologia 110 (1997) 160-168.

[25] Ritchie G.A., Carbohydrate reserves and root growth potential in Douglas-fir seedlings before and after cold storage, Can. J. For. Res. 12 (1982) 905-912.
[26] Ritchie G.A., Relationships among bud dormancy status, cold hardiness, and stress resistance in $2+0$ Douglas-fir, New For. 1 (1986) $29-42$.

[27] Ritchie G.A., Hinckley T.M., The pressure chamber as an instrument for ecological research, Adv. Ecol. Res. 9 (1975) 165-254.

[28] Seiler J.R., Cazell B.H., Influence of water stress on the physiology and growth of red spruce seedlings, Tree Physiol. 6 (1990) 69-77.

[29] Snedecor G.W., Cochran W.G., Statistical methods, The Iowa State University Press, Ames, Iowa, USA, 1967.

[30] Thiffault N., Jobidon R., Munson A.D., Performance and physiology of large containerized and bare-root spruce seedlings in relation to scarification and competition in Québec (Canada), Ann. For. Sci. 60 (2003) 645-655.

[31] Tranquillini W., Physiological ecology of the Alpine timberline, Springer-Verlag, New York, 1979.

[32] Van den Driessche R., Importance of current photosynthate to new root growth in planted conifer seedlings, Can. J. For. Res. 17 (1987) 776-782.

[33] Van den Driessche R., Influence of container nursery regimes on drought resistance of seedlings following planting, 1, Survival and growth, Can. J. For. Res. 21 (1991) 555-565. 